Article

\title{
Essential Oil from Pinus Koraiensis Pinecones Inhibits Gastric Cancer Cells via the HIPPO/YAP Signaling Pathway
}

\author{
Yandong Zhang ${ }^{1}$, Chao Xin ${ }^{1}$, Junqiang Qiu ${ }^{2}$ and Zhenyu Wang ${ }^{1, *}$ \\ 1 Department of Food Science and Engineering, School of Chemistry and Chemical Engineering, Harbin \\ Institute of Technology, Harbin 150090, China; 15604805165@163.com (Y.Z.); xinchao198811@126.com (C.X.) \\ 2 Department of Inorganic Chemistry and Analytical Chemistry, School of Pharmacy, Hainan Medical \\ University, Haikou 570100, China; qjq000000@163.com \\ * Correspondence: 15B928012@hit.edu.cn
}

Received: 17 September 2019; Accepted: 22 October 2019; Published: 25 October 2019

\begin{abstract}
Pinecone is a traditional folk herb, which has been used in China for many years. In this paper, the essential oil from Pinus koraiensis pinecones (PEO) was obtained by hydrodistillation and 41 compounds were identified by gas chromatography-mass spectrometry (GC-MS), mainly including $\alpha$-Pinene (40.91\%), Limonene (24.82\%), and $\beta$-Pinene (7.04\%). The purpose of this study was to investigate the anti-tumor activity of PEO on MGC-803 cells and its mechanism. Anti-tumor experiments in vitro showed PEO could significantly inhibit the proliferation and migration of MGC-803 cells, and it also could arrest the cell cycle in the G2/M phase, decrease the mitochondrial membrane potential, and induce apoptosis. Finally, the effects of PEO on genes expression on MGC-803 cells were analyzed by RNA sequencing, and results showed that after treatment with PEO, 100 genes were up-regulated, and 57 genes were down-regulated. According to the KEGG pathway and GSEA, FAT4, STK3, LATS2, YAP1, and AJUBA were down-regulated, which were related to HIPPO signaling pathway. Real-time PCR and western blot further confirmed the results of RNA sequencing. These results indicated that PEO may exert anti-tumor activity via the HIPPO/YAP signaling pathway. The anti-tumor mechanism of this oil can be further studied, which is important for the development of anti-tumor drugs.
\end{abstract}

Keywords: pinecone; essential oil; gastric cancer; RNA sequencing; HIPPO/YAP signaling pathway

\section{Introduction}

Gastric cancer is one of the most common malignancies, with about one million new cases diagnosed each year, ranking third in cancer-related deaths worldwide [1]. Gastric cancer is often diagnosed at a later stage because of the lack of early symptoms, and the frightening is the poor prognosis and limited treatment options [2]. At present, surgical resection, radiotherapy, and chemotherapy are the main methods for the treatment of gastric cancer [3]. Although chemotherapy is a more effective treatment for potential metastatic and metastatic gastric cancer, the currently applied chemotherapy drugs for gastric cancer are difficult to satisfy [4]. In order to improve the side effects and drug resistance of traditional chemotherapy drugs, more and more researches have focused on the development of natural anti-tumor drugs, including natural polyphenols [5], polysaccharides [6], and terpenoids [7].

Essential oils (EOs) have been paid more and more attention due to their unique properties, which play an important role in natural products $[8,9]$. It has been reported that EOs have many physiological activities, such as antioxidant [10], antibacterial [11], anti-inflammatory [12], anti-tumor [13] and anti-insect [14]. Pinus koraiensis is a traditional plant belonging to genus of Pinus in the family of Pinaceae [15]. Pinecone is an important organ of Pinus koraiensis, with the effects of antitussive, 
expectorant and anti-inflammatory, and it is rich in essential oil. In addition, Pinus koraiensis pinecones extracts had a variety of physiological activities such as anti-tumor, anti-angiogenesis, and anti-radiation [16-18]. According to reports, pine needle essential oils (from four Pinus genera: p. mugo subsp. Mugo, P. nigra subsp. Nigra, P. sylvestris, and P. peuce) had good antimicrobial and insect larvicidal activities [19]. Earlier, the pine needle extract of Cedrus deodara was also proven to be a good natural antioxidant [20]. However, there are few reports about Pinus koraiensis pinecones essential oil (PEO). Therefore, it was useful for the development of natural anti-tumor drugs to explore the anti-tumor activity of PEO.

HIPPO signaling pathway is a highly conserved cellular signal transduction pathway, which was first found in Drosophila [21]. HIPPO pathway controls organ size and cell differentiation by regulating cell proliferation and apoptosis, which is of great significance for the development of tumors [22]. The core of this pathway is a kinase cascade composed of STK3/4-LATS1/2-YAP/TAZ [23]. YAP/TAZ is the main effector of HIPPO pathway, and dephosphorylated YAP/TAZ promotes the transcription of genes regulating proliferation and migration after entering the nucleus [21]. It has been reported that YAP is highly expressed in various tumors, including gastric cancer [24]. More and more studies have proved that YAP can promote the proliferation and metastasis of tumors, which is extremely unfavorable to the prognosis of cancer patients $[25,26]$. Therefore, it is meaningful to study the potential mechanism of HIPPO/YAP signaling pathway in the proliferation and apoptosis of cancer cells.

In this study, we identified the components of PEO and analyzed its therapeutic potential and mechanism on MGC-803 cells based on RNA sequencing and bioinformatics analysis, which was necessary for the development of anti-tumor drugs.

\section{Results}

\subsection{Chemical Composition of Essential Oil}

GC-MS is the most commonly used method for the analysis of essential oils components at present $[27,28]$. The yellow PEO with characteristic odor was obtained by hydrodistillation and 41 components were identified by GC-MS, accounting 95.73\% of the total oil (Table 1), and the main components were respectively $\alpha$-Pinene (40.91\%), Limonene (24.82\%), and $\beta$-Pinene (7.04\%). It was similar to the chemical composition of oils from fresh needles with different pinus species [19,29]. Figure 1 shows sensitive signals in the total ion currency (TIC) profile. The sequence numbers of the peaks in Figure 1 were consistent with those of the compounds in Table 1.

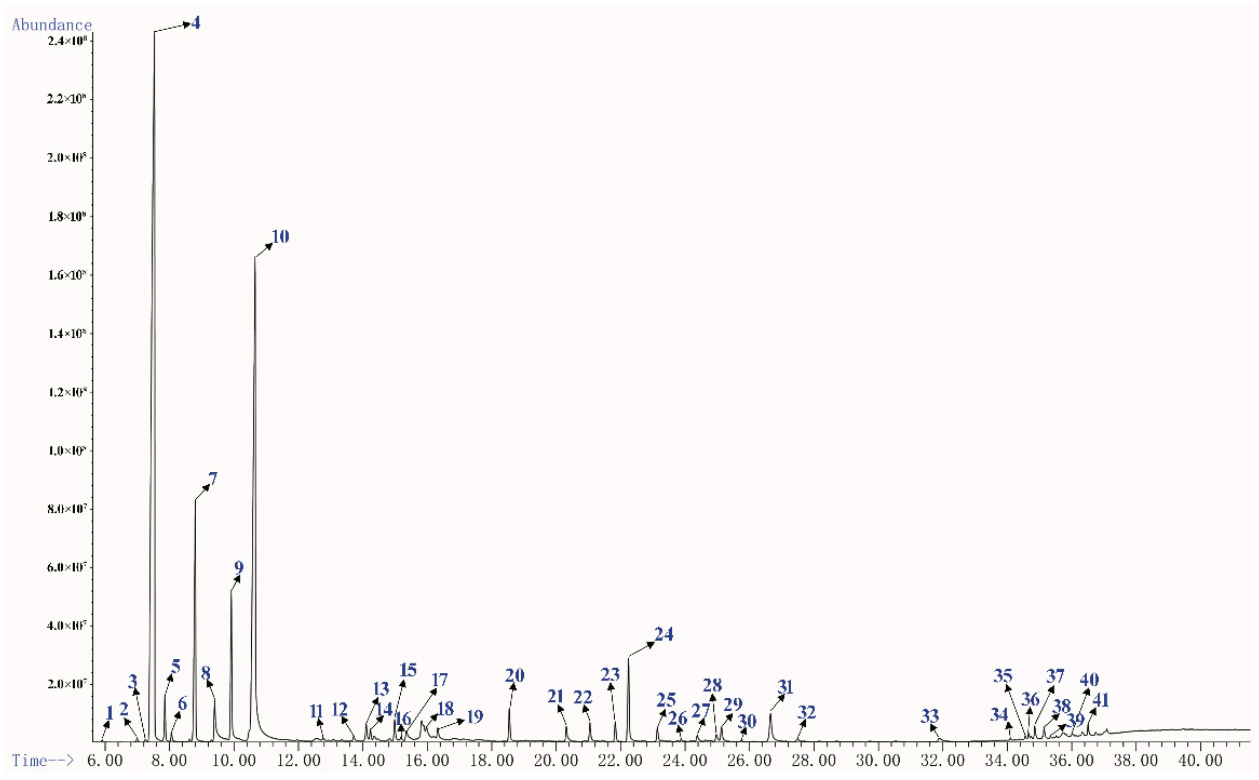

Figure 1. The total ion currency (TIC) profile of PEO. 
Table 1. GC-MS analysis results of PEO components.

\begin{tabular}{|c|c|c|c|c|}
\hline No. & Compounds & $\mathbf{R I}^{\mathbf{a}}$ & $\mathbf{R I}^{\mathbf{b}}$ & $\%$ \\
\hline 1 & Santene & 882 & 884 & 0.06 \\
\hline 2 & Tricyclene & 918 & 919 & 0.11 \\
\hline 3 & Bicyclo [3.1.0]hexane, 4-methyl-1-(1-methylethyl)-didehydro deriv. & 926 & - & 0.11 \\
\hline 4 & $\alpha$-Pinene & 934 & 934 & 40.91 \\
\hline 5 & Camphene & 944 & 945 & 1.08 \\
\hline 6 & Cosmene & 968 & - & 0.07 \\
\hline 7 & $\beta$-Pinene & 973 & 972 & 7.04 \\
\hline 8 & $\beta$-Myrcene & 992 & 992 & 2.04 \\
\hline 9 & 3-Carene & 1008 & 1007 & 4.12 \\
\hline 10 & Limonene & 1030 & 1031 & 24.82 \\
\hline 11 & Bicyclo [3.1.0]hexane, 6-isopropylidene-1-methyl- & 1088 & - & 0.24 \\
\hline 12 & L-trans-Pinocarveol & 1138 & 1140 & 0.58 \\
\hline 13 & L-camphor & 1142 & 1142 & 0.35 \\
\hline 14 & cis-Verbenol & 1145 & 1137 & 0.24 \\
\hline 15 & Pinocarvone & 1161 & 1162 & 0.13 \\
\hline 16 & Borneol & 1166 & 1160 & 0.64 \\
\hline 17 & 3-Pinanone & 1173 & - & 0.15 \\
\hline 18 & 4-Terpineol & 1178 & 1177 & 0.59 \\
\hline 19 & p-menth-1-en-8-ol & 1193 & 1192 & 1.41 \\
\hline 20 & Myrtenol & 1197 & 1195 & 0.80 \\
\hline 21 & Verbenone & 1209 & 1205 & 0.58 \\
\hline 22 & L- $\alpha$-bornyl acetate & 1285 & 1287 & 0.92 \\
\hline 23 & $\alpha$-Longipinene & 1349 & 1350 & 0.55 \\
\hline 24 & Copaene & 1375 & 1375 & 0.57 \\
\hline 25 & D-longifolene & 1404 & 1405 & 0.59 \\
\hline 26 & $\beta$-Caryophyllen & 1419 & 1420 & 2.57 \\
\hline 27 & $\alpha$-Caryophyllen & 1454 & 1452 & 0.43 \\
\hline 28 & $\gamma$-Muurolene & 1477 & 1478 & 0.06 \\
\hline 29 & Germacrene D & 1482 & 1484 & 0.11 \\
\hline 30 & $\alpha$-Muurolene & 1501 & 1502 & 0.26 \\
\hline 31 & $\alpha$-Himachalene & 1510 & 1500 & 0.07 \\
\hline 32 & $(+)-\delta$-Cadinene & 1523 & 1526 & 0.29 \\
\hline 33 & Caryophyllene oxide & 1583 & 1585 & 1.48 \\
\hline 34 & $\alpha$-Humulene oxide II & 1610 & 1608 & 0.12 \\
\hline 35 & Pentyl cinnamate & 1760 & - & 0.27 \\
\hline 36 & Cembrene & 1941 & 1944 & 0.06 \\
\hline 37 & 1-Heptatriacotanol & 1956 & - & 0.02 \\
\hline 38 & 4b,8-Dimethyl-2-isopropylphenanthrene, $4 \mathrm{~b}, 5,6,7,8,8 \mathrm{a}, 9,10$-octahydro- & 1995 & - & 0.48 \\
\hline 39 & Manoyl oxide & 2009 & - & 0.17 \\
\hline 40 & $\begin{array}{c}\text { 7-Isopropyl-1,1,4a-trimethyl-1,2,3,4,4a,9,10,10a-octahydrophenanthrene } \\
\text { 1-Phenanthrenecarboxaldehyde, }\end{array}$ & 2079 & - & 0.34 \\
\hline \multirow[t]{2}{*}{41} & $\begin{array}{c}\text { 1,2,3,4,4a,9,10,10a-octahydro-1,4a-dimethyl-7-(1-methylethyl)-, } \\
\text { [1R-(1. } \alpha, 4 \text { a. } \beta, 10 \text { a. } \alpha)]-\end{array}$ & 2316 & - & 0.30 \\
\hline & Total & & & 95.73 \\
\hline
\end{tabular}

${ }^{a}$ Retention index determined on a DB-5-MS capillary column relative to a series of n-alkanes (C8-C40). ${ }^{b}$ Retention index reported from the literature $[19,29,30]$.

\subsection{Anti-Tumor Activity of PEO In Vitro}

\subsubsection{Cell Cytotoxicity Activity In Vitro}

The MTT assay showed that PEO and paclitaxel (PTX) had an obvious cytotoxic activity on MGC-803 cells (Figure 2A,B). As a result, the PEO exhibited a potential growth inhibitory effect on the MGC-803 cells with the $\mathrm{EC}_{50}$ were $223.01 \pm 5.93 \mu \mathrm{g} / \mathrm{mL}$ at $24 \mathrm{~h}, 46.17 \pm 3.35 \mu \mathrm{g} / \mathrm{mL}$ at $48 \mathrm{~h}$, and $22.36 \pm 1.02 \mu \mathrm{g} / \mathrm{mL}$ at $72 \mathrm{~h}$. Under the same conditions, the $\mathrm{EC}_{50}$ of PTX were $8.29 \pm 0.47 \mu \mathrm{g} / \mathrm{mL}$ at $24 \mathrm{~h}, 4.44 \pm 0.11 \mu \mathrm{g} / \mathrm{mL}$ at $48 \mathrm{~h}$, and $3.22 \pm 0.08 \mu \mathrm{g} / \mathrm{mL}$ at $72 \mathrm{~h}$, respectively. These indicated that the PEO had good anti-proliferative activity on MGC-803 cells, and the anti-proliferative activity was 
gradually enhanced with the increase of concentration and treatment time of essential oil. This was a dose- and time-dependent manner, which was reflected in many medicines.
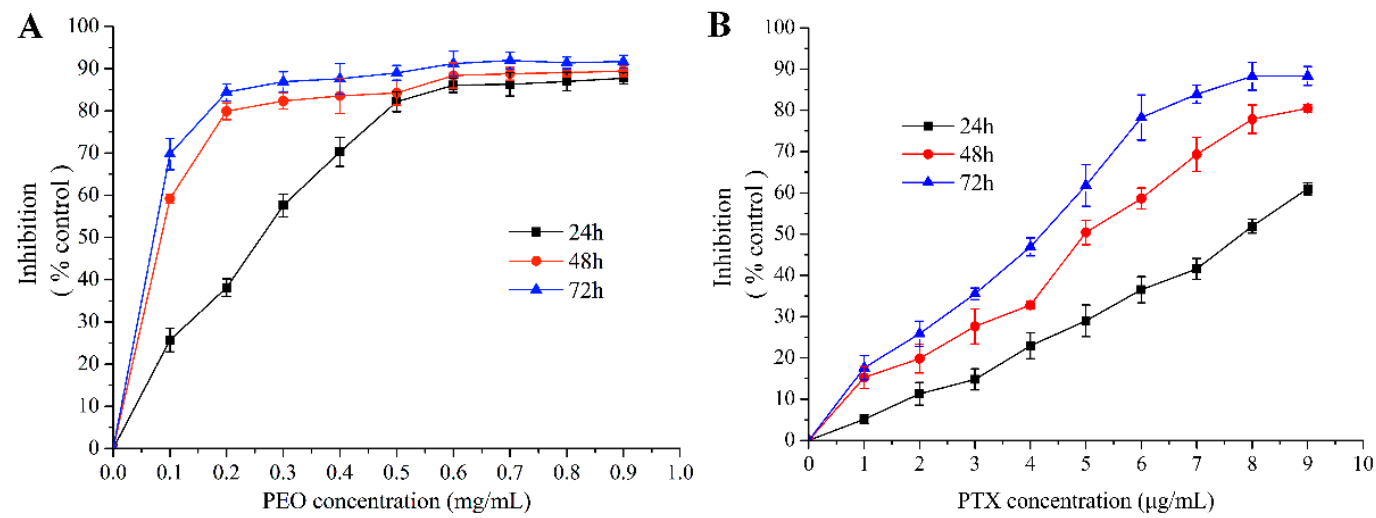

Figure 2. Cytotoxic effects of PEO on MGC-803 cells by MTT assay for 24, 48, and $72 \mathrm{~h}$.

\subsubsection{Cell Migration Capacity Analysis}

Cell scratch assay is a simple and rapid method to measure cell migration and repair ability [31]. As shown in Figure 3, compared with the control group, the cell migration ability of the low, middle, and high dose groups decreased significantly $\left({ }^{* * *} p<0.001\right)$. The results showed that the PEO could inhibit the migration of MGC- 803 cells, and the migration rates were decreased with the increase of the concentration of PEO.
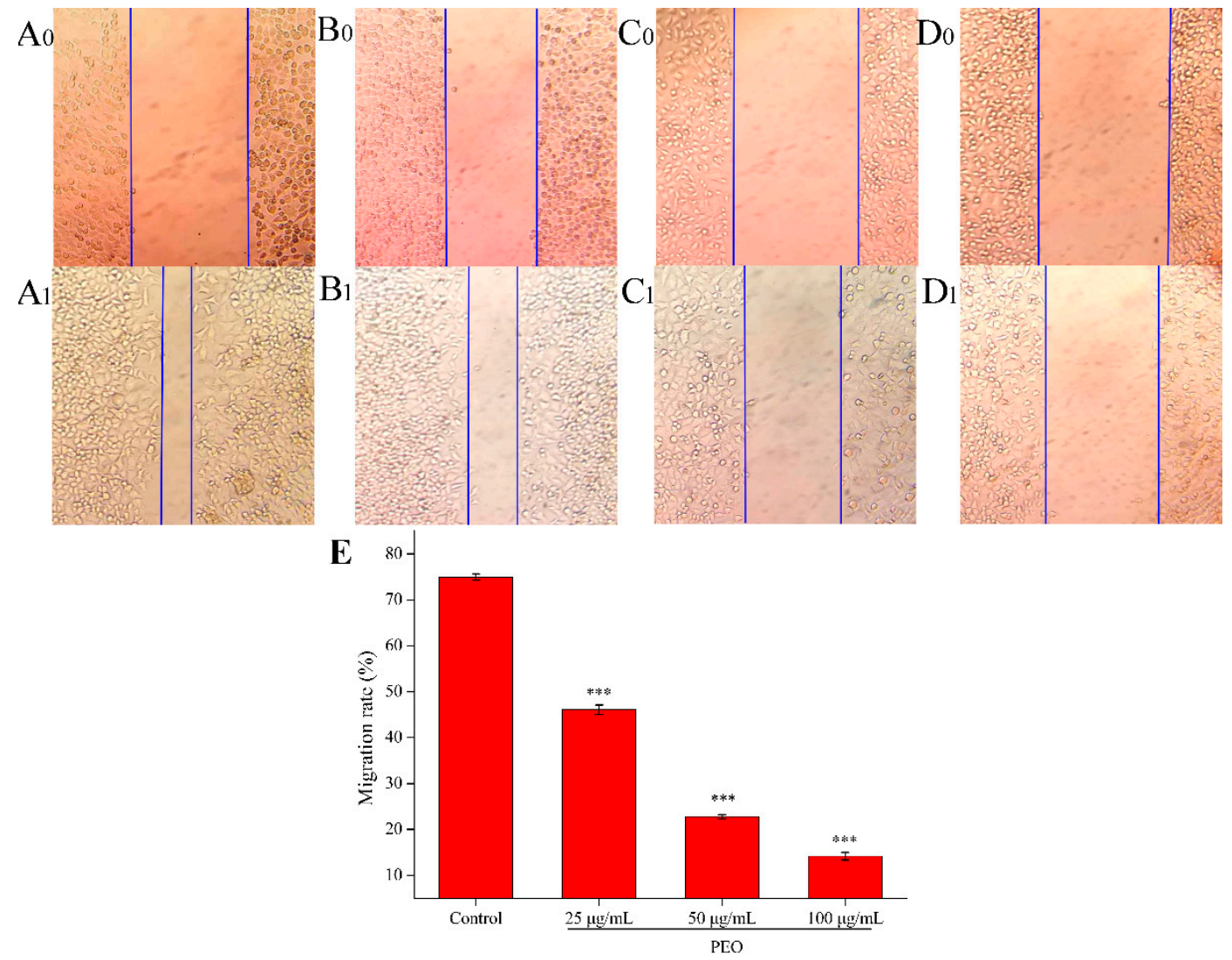

Figure 3. Effects on MGC-803 cell migration capacity. The A-D represented PEO concentrations were $0,25,50$, and $100 \mu \mathrm{g} / \mathrm{mL}$, the subscript 0 and 1 that represented the photos $(100 \times)$ were taken after MGC 803 cells exposing to the PEO 0 and $24 \mathrm{~h}$, respectively; $\mathrm{E}$ was the migration rates of experimental groups that treated $24 \mathrm{~h}$ with PEO compared with $0 \mathrm{~h}(* * * p<0.001)$. 


\subsubsection{Cell Cycle Analysis}

Many anti-tumor drugs may inhibit the proliferation of tumor cells through cell cycle arrest [32,33]. As shown in Figure 4, PEO led to significant changes of cell cycle progression. Compared with control, when MGC-803 cells were treated with different concentrations of PEO $(25,50$, or $100 \mu \mathrm{g} / \mathrm{mL})$ for $24 \mathrm{~h}$, the percentage of cells in the G2/M phase fraction increased from $17.87 \%$ to $19.99 \%, 34.03 \%$, or $31.01 \%$, respectively. This indicated that PEO can significantly arrest the MGC-803 cells in the G2/M phase $\left({ }^{*} p<0.05,{ }^{* * *} p<0.001\right)$.
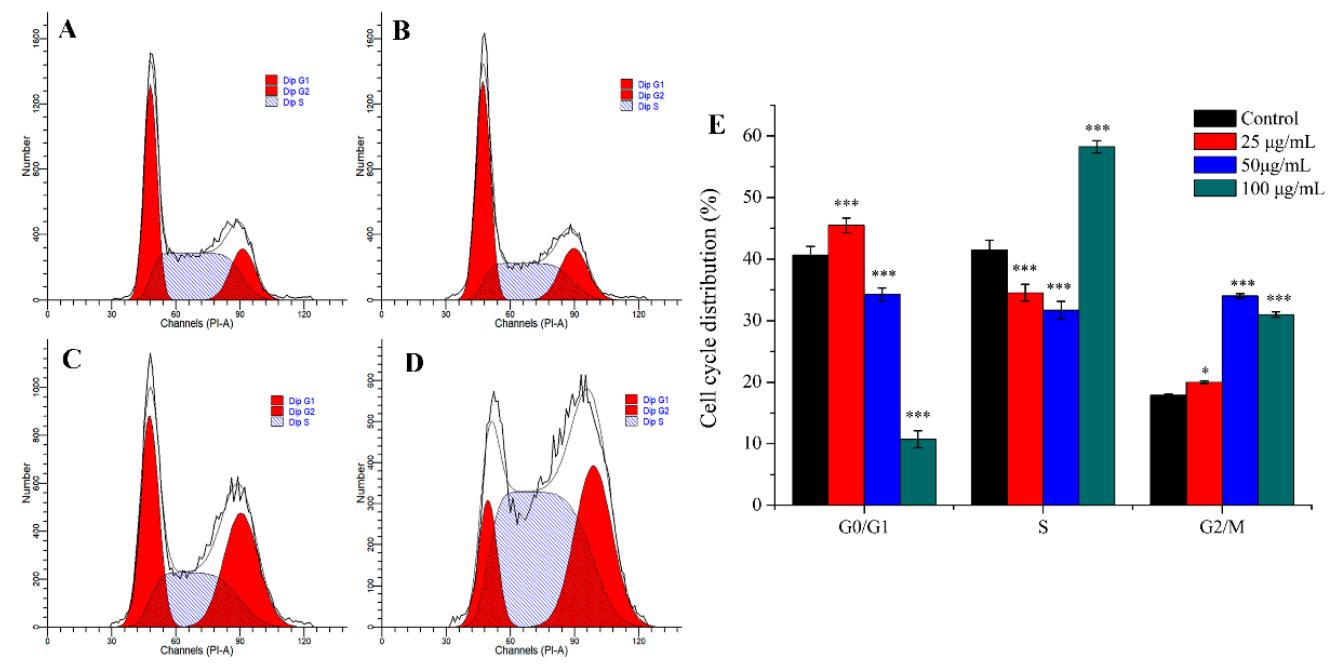

Figure 4. Cell cycle analysis of MGC-803 cells treated by PEO for $24 \mathrm{~h}$. The A-D represented PEO concentrations were $0,25,50$, and $100 \mu \mathrm{g} / \mathrm{mL}$, respectively; The E was the numerical histogram of cell cycle distribution $\left({ }^{*} p<0.05,{ }^{* * *} p<0.001\right)$.

\subsubsection{Cell Apoptosis Analysis}

Apoptosis is the most common way of tumor cells death induced by chemotherapeutic drugs, and it is the main way in which most natural anti-tumor drugs play their roles [34,35]. As shown in Figure 5, the apoptotic rate of the control group was $5.60 \%$, while the three experimental groups were $17.31 \%$ $(25 \mu \mathrm{g} / \mathrm{mL}), 23.22 \%(50 \mu \mathrm{g} / \mathrm{mL})$, and 30.30\% $(100 \mu \mathrm{g} / \mathrm{mL})$, respectively. Compared with the control group, the apoptotic rates in the three dose groups were significantly different $\left.{ }^{* * *} p<0.001\right)$, and the apoptotic rates were increased with the increase of PEO concentration. These results demonstrate that PEO can induce apoptosis of MGC-803 cells in a dose-dependent manner.

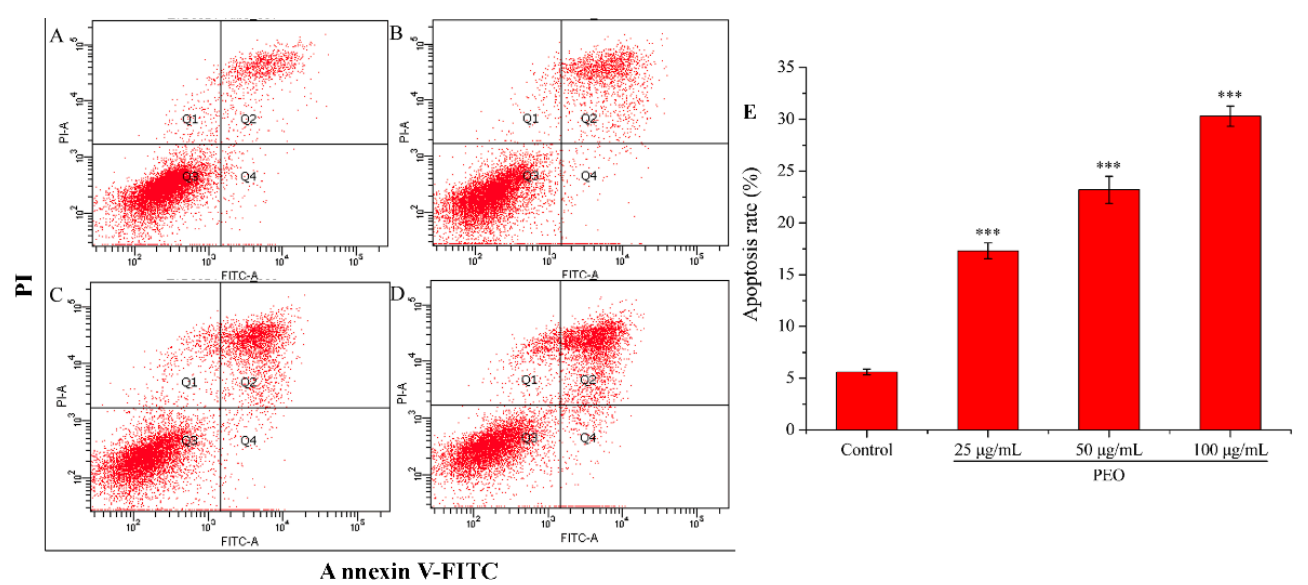

Figure 5. Cell apoptosis analysis of MGC-803 cells treated by PEO for $24 \mathrm{~h}$. The A-D represented PEO concentrations were $0,25,50$, and $100 \mu \mathrm{g} / \mathrm{mL}$, respectively; The E was the numerical histogram of apoptosis rate $(* * * 0.001)$. 


\subsubsection{Analysis of Mitochondrial Membrane Potential}

The mitochondrial membrane potential of MGC-803 cells was decreased significantly after being treated by PEO (Figure 6). As shown in Figure 6A-D, with the increase of PEO concentration, the number of JC-I monomer was increased from $0.9 \%$ to $31.0 \%$. Compared with the control group, the rates of JC-I monomer/aggregate in the three dose groups were significantly different (Figure $6 \mathrm{E},{ }^{* * *} p<0.001$ ). These further indicated that PEO can induce apoptosis of MGC-803 cells.
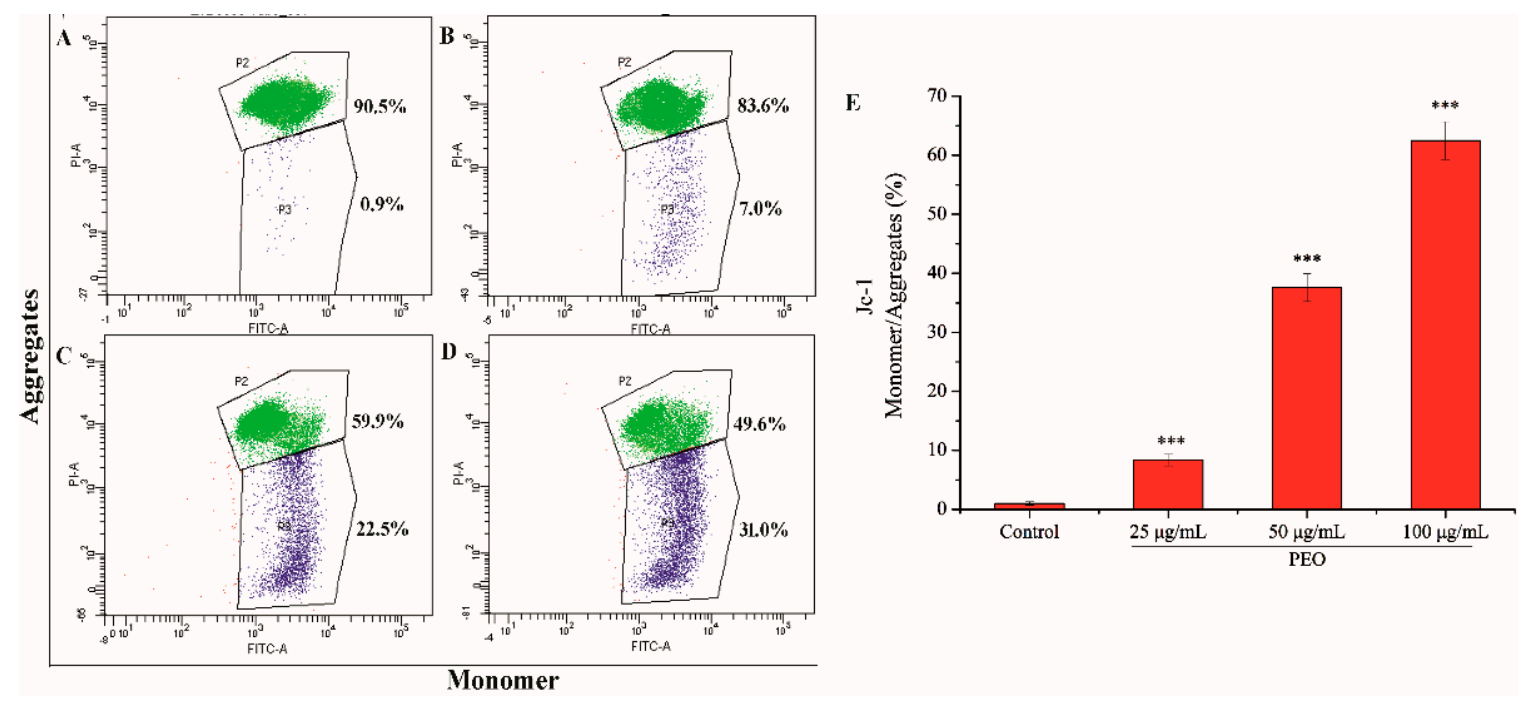

Figure 6. Cell apoptosis analysis of MGC-803 cells treated by PEO for $24 \mathrm{~h}$. The A-D represented PEO concentrations were $0,25,50$, and $100 \mu \mathrm{g} / \mathrm{mL}$, respectively; The E was the numerical histogram of the ratio of JC-1 monomer to aggregates $\left.{ }^{* * *} p<0.001\right)$.

\subsection{RNA Sequencing Analysis}

\subsubsection{Screening for Differentially Expressed Genes (DEGs)}

After treatment of MGC-803 cells with $50 \mu \mathrm{g} / \mathrm{mL}$ PEO for $24 \mathrm{~h}$, RNA sequencing analysis indicated that there were 157 differentially expressed genes (100 up-regulated and 57 down-regulated) in the experimental groups compared with the control (Figures 7 and 8). The top 10 differentially expressed genes were presented in Table 2.

Table 2. Top 10 differentially expressed genes in MGC-803 cells (PEO treatment versus control).

\begin{tabular}{cccccc}
\hline Rank & Gene Name & Gene Feature & log2fc & Fold Change & $p$-Value \\
\hline 1 & SLC7A11 & Up-regulated & 2.35 & 5.10 & $3.50 \times 10^{-6}$ \\
2 & A2M & Down-regulated & -1.14 & 0.45 & $2.40 \times 10^{-5}$ \\
3 & ALPP & Down-regulated & -1.36 & 0.39 & $2.71 \times 10^{-5}$ \\
4 & HTRA3 & Up-regulated & 1.76 & 3.38 & $4.11 \times 10^{-5}$ \\
5 & AKR1C2 & Up-regulated & 1.71 & 3.27 & $9.99 \times 10^{-5}$ \\
6 & AKR1C1 & Up-regulated & 2.59 & 6.04 & $1.32 \times 10^{-4}$ \\
7 & HMOX1 & Up-regulated & 2.08 & 4.24 & $2.76 \times 10^{-4}$ \\
8 & AC069257.3 & Down-regulated & -1.11 & 0.46 & $6.14 \times 10^{-4}$ \\
9 & ALPI & Down-regulated & -1.24 & 0.42 & $9.15 \times 10^{-4}$ \\
10 & CA9 & Down-regulated & -1.06 & 0.48 & $3.71 \times 10^{-3}$ \\
\hline
\end{tabular}




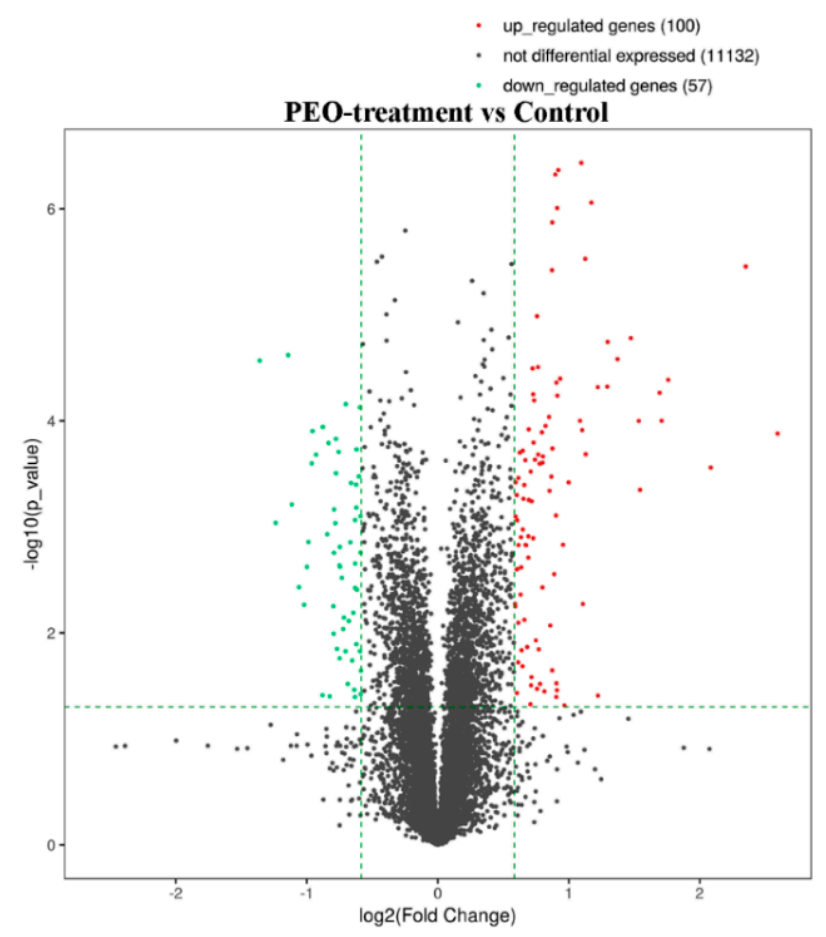

Figure 7. The volcano plot of mRNA. The vertical two green lines were up-regulated (right side) and down-regulated (left side), respectively. The green parallel lines corresponded to the $p$-value threshold. Green dots represent down-regulated genes with significant differences, red dots represent up-regulated genes with significant differences, and gray dots represent non-significant different genes.

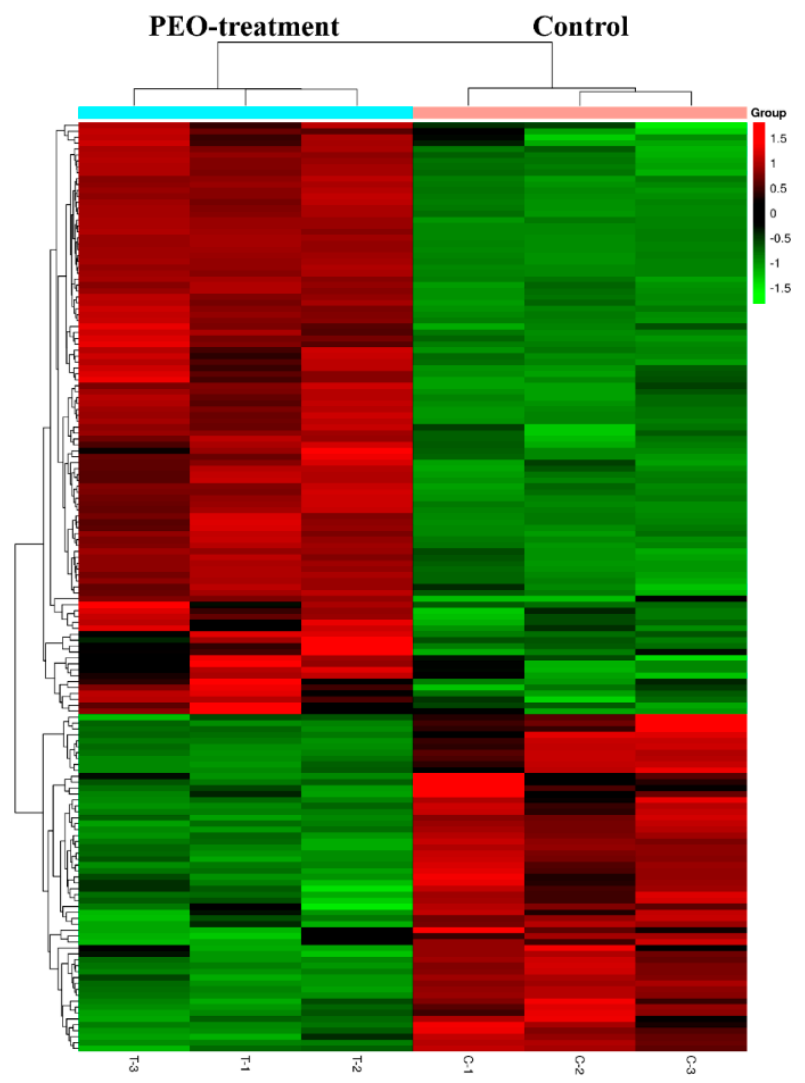

Figure 8. Heat map of DEGs with fold change expression $>1.5$. MGC-803 cells were treated with $50 \mu \mathrm{g} / \mathrm{mL}$ PEO or control for $24 \mathrm{~h}(n=3)$. Rows represent genes and columns represent samples. Red blocks represent high and green blocks low expression relative to comparison cells. 


\subsubsection{Functional and Pathway Enrichment Analyses}

GO analysis of DEGs was performed to determine the main functions of PEO on MGC-803 cells inhibition. The top 10 GO items (BP, CC, MF) and KEGG pathways with the most significant difference in the results was shown in Figure 9. According to the results of KEGG pathway and GSEA, we found that the changes of HIPPO signaling pathway were the most significant in cancer-related signaling pathways (experimental groups versus control groups). The genes of FAT4, STK3, LATS2, YAP1, and AJUBA were all down-regulated $(* p<0.05)$. Among them, YAP1 is the crucial effector of HIPPO signaling pathway, and plays a key role in HIPPO signaling pathway [36]. We speculated that the PEO inhibited the proliferation of MGC-803 cells maybe by regulating the HIPPO signaling pathway. Next, we verified the difference of FAT4, STK3, LATS2, YAP1, and AJUBA genes expression on MGC-803 cells treated with PEO or control by real-time PCR.

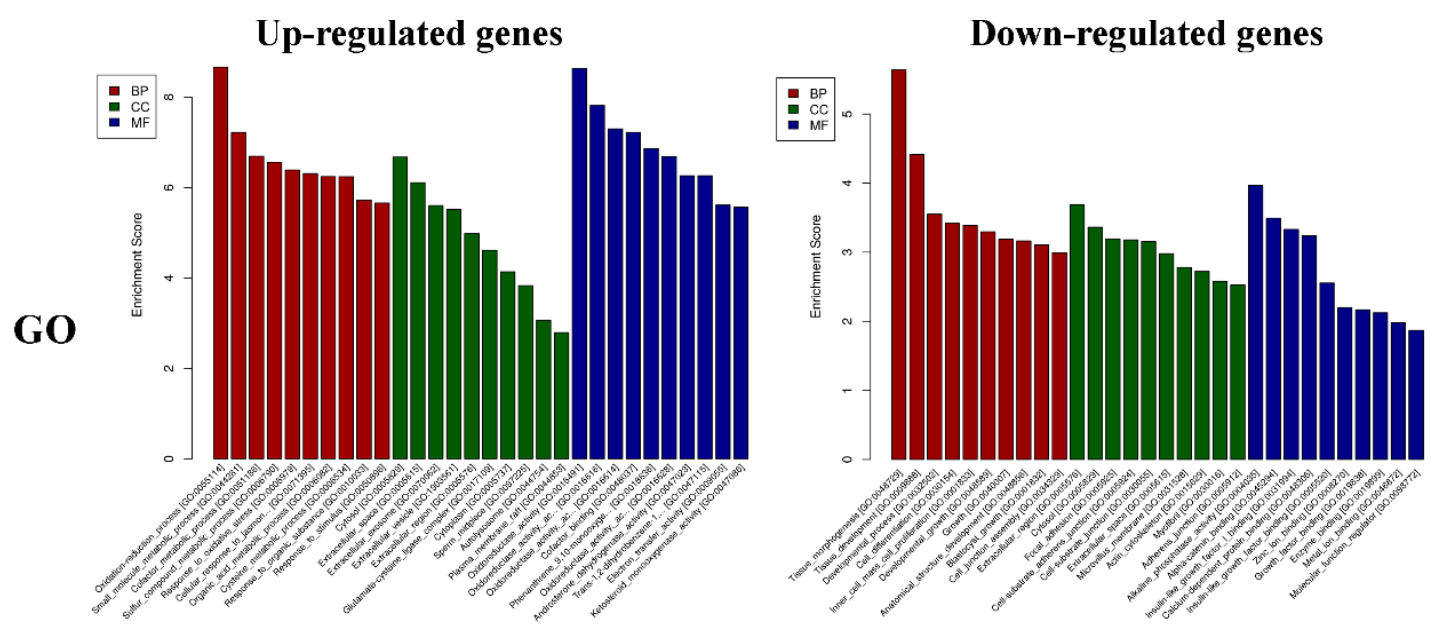

\section{Up-regulated genes}

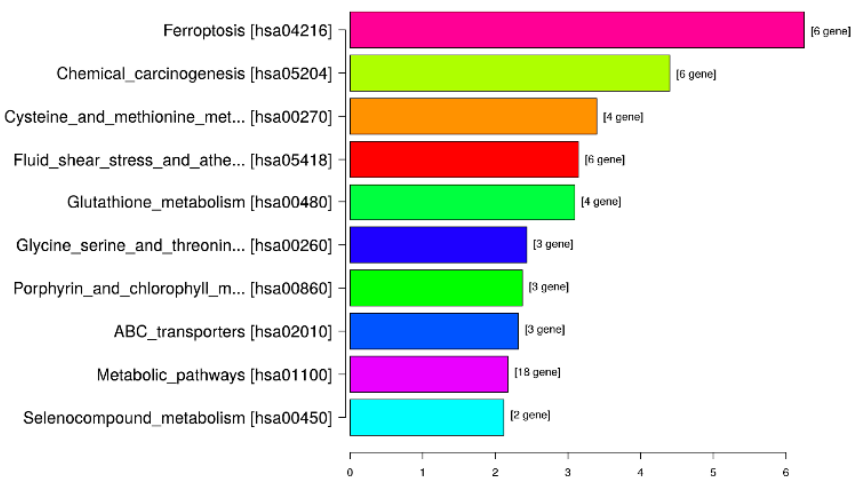

KEGG

\section{Down-regulated genes}

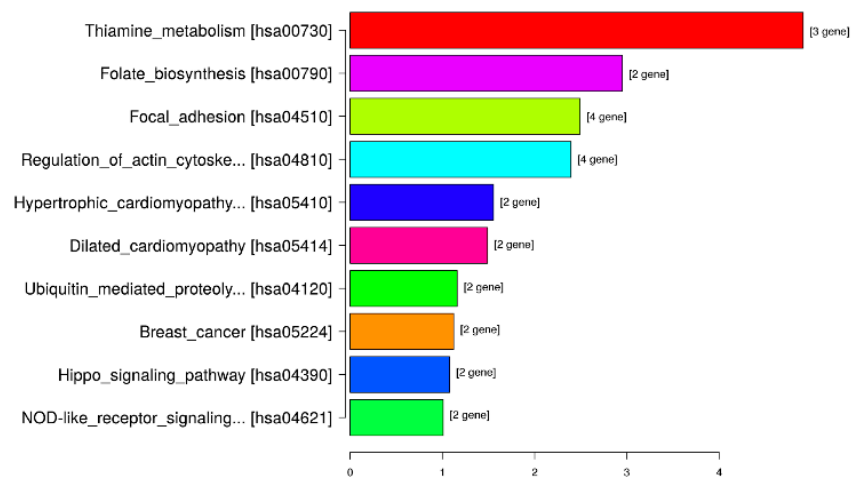

Figure 9. Results of functional and pathway enrichment analyses. GO: Gene ontology, KEGG: Kyoto encyclopedia of genes and genomes. 


\subsubsection{Real-Time PCR Analysis}

Real-time PCR was performed for genes quantitative analysis to confirm the changes of genes in RNA sequencing results. We selected five genes (FAT4, STK3, LATS2, YAP1, and AJUBA) which were related to HIPPO signaling pathway. As shown in Figure 10, the relative expression in each gene (FAT4, STK3, LATS2, YAP1, or AJUBA) were similar between real-time PCR and RNA Sequencing. Compared with the control group, the expression levels in the experimental groups were significantly down-regulated $\left({ }^{*} p<0.05,{ }^{* *} p<0.01,{ }^{* * *} p<0.001\right)$. This showed that RNA Sequencing was properly performed and the PEO could regulate HIPPO signaling pathway.

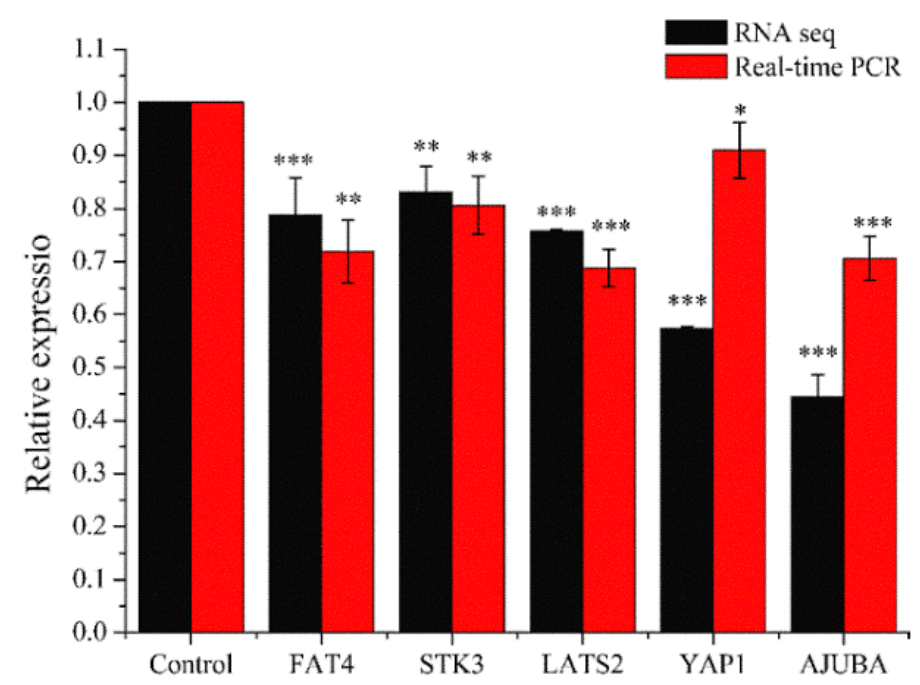

Figure 10. Results of real-time PCR. MGC-803 cells were treated with $50 \mu \mathrm{g} / \mathrm{mL}$ PEO or control for $24 \mathrm{~h}$ $\left({ }^{*} p<0.05,{ }^{* *} p<0.01,{ }^{* * *} p<0.001, n=3\right)$.

\subsubsection{Western Blot Analysis}

Western blot was used to check the expression of five proteins (FAT4, STK3, LATS2, YAP1, and AJUBA). As shown in Figure 11, compared with the control group, the expression levels of FAT4, STK3, LATS2, YAP1, and AJUBA proteins were significantly down-regulated in a dose-dependent manner when treated with PEO for $24 \mathrm{~h}\left({ }^{*} p<0.05,{ }^{* *} p<0.01,{ }^{* * *} p<0.001\right)$. The results were consistent with the RNA sequencing and real-time PCR. 

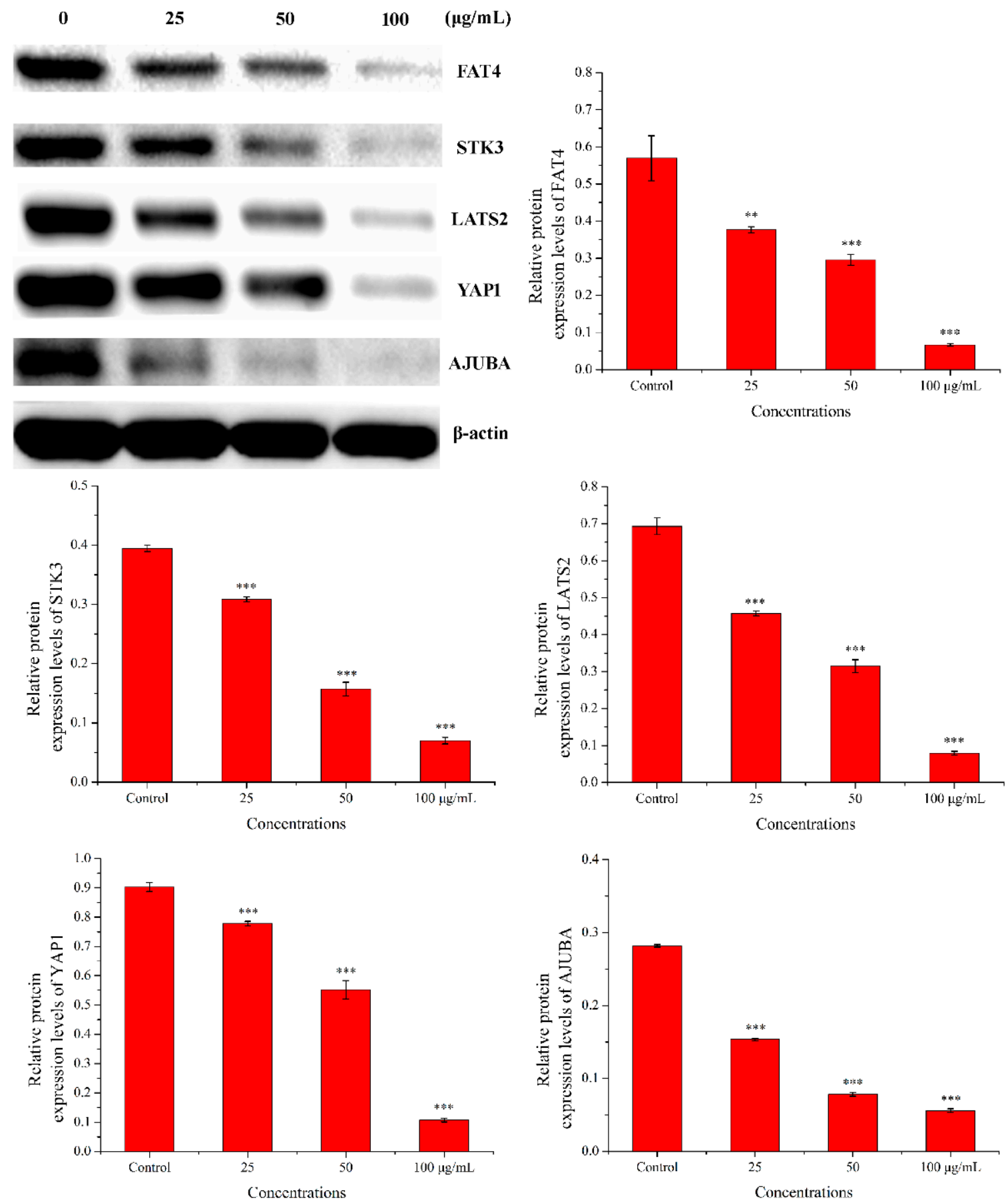

Figure 11. Results of western blot. MGC-803 cells were treated with $0,25,50$, and $100 \mu \mathrm{g} / \mathrm{mL}$ PEO for $24 \mathrm{~h}\left(n=3{ }^{* *} p<0.01 ;{ }^{* * *} p<0.001\right)$.

\section{Discussion}

EOs are an important source of natural antioxidant, antibacterial, anti-inflammatory, and anti-tumor agents, and have received more and more attention [37-39]. The chemical constituents and relative contents of EOs are not only related to raw materials, but also to extraction methods [40]. EO is a mixture of various small molecule compounds that exerts its physiological activities as a combination drug. For example, Galdino et al. [41] reported that the essential oil derived from Spiranthera odoratissima leaves and its main component ( $\beta$-caryophyllene) had anxiolytic-like effects, but their effects and mechanisms were completely different. Therefore, it is difficult to determine 
whether a component plays a leading role, whether it is the most abundant or not. Nevertheless, the difference in composition and content is still an important factor affecting the quality of EOs [42].

As a result, terpenes were the main components of PEO extracted by hydrodistillation, mainly including $\alpha$-Pinene (40.91\%) and Limonene (24.82\%). It is reported that both $\alpha$-Pinene and Limonene had anti-tumor activity, which can inhibit the proliferation of a variety of human tumor cells, including prostate cancer, breast cancer, liver cancer, and gastric cancer cells [43,44]. Chen et al. [45] found that $\alpha$-Pinene had good anti-tumor activity in vitro and in vivo, and it can inhibit the proliferation of BEL-7402 cells by arresting the cell cycle in the G2/M phase. However, the anti-tumor activity of Limonene is weak, and it is usually necessary to synthesize Limonene derivatives to enhance its anti-tumor activity [46]. In this study, the anti-tumor activity experiments showed that PEO could significantly inhibit the proliferation and migration of MGC-803 cells, arrest cell cycle in G2/M phase, and finally induce apoptosis $(p<0.05)$. These results proved that PEO had good anti-tumor activity, similar to many EOs that had been reported [47,48].

Most of the reports were based on the above experiments to prove the anti-tumor activity of EOs, but the anti-tumor mechanism was not very clear. This was closely related to the complex pathogenesis of tumors. However, the wide application of RNA sequencing technology facilitated the study of the mechanism of anti-tumor drugs [49]. RNA sequencing is currently the preferred technology for gene expression analysis, and it could quickly and accurately detect the differences of gene expression among different groups [50]. In this study, RNA sequencing revealed 157 differentially expressed genes in the PEO-treated groups compared with the control groups $(p<0.05)$. According to the KEGG pathway and GSEA analysis, HIPPO signaling pathway is the key to the anti-tumor effect of PEO on MGC-803 cells. As a result, genes associated with HIPPO signaling pathways were significantly down-regulated, including FAT4, STK3, LATS2, YAP1, and AJUBA $(p<0.05)$.

HIPPO signaling pathway is an acknowledged anti-tumor pathway, which has been widely studied [22]. FAT4 is a multiple upstream signal input factor of HIPPO signaling pathway, and STK3 and LATS2 are crucial in the core kinase cascade. YAP1 is the effector of Hippo signaling pathway with important functions in cell proliferation, apoptosis, invasion, and migration [51]. AJUBA function as negative regulators of the Hippo pathway, affecting cell proliferation and controlling tissue size [52]. The central axis of the pathway comprises a phosphorylation cascade of STK3/4-LATS1/2-YAP/TAZ in humans, and it plays an important role in the development of tumors [53].

YAP is identified as a well-characterized human oncogene and it is highly expressed in several types of cancers including gastric [54]. Our results demonstrated that PEO can down-regulate the expression of YAP1, which may be the reason why PEO inhibits the proliferation and migration of MGC803 cells and promoting apoptosis. In addition, AJUBA LIM proteins interact with LATS/Wts and WW45/Sav to inhibit phosphorylation of YAP1 and up-regulates Cyclin E and DIAPI, thereby promoting cell proliferation [55]. In this study, the down-regulation of LATS2 and AJUBA may lead to the enhancement of YAP1 phosphorylation, decrease its activity in the nucleus and inhibit the proliferation of MGC-803 cells. As the study of Li et al. [56], AJUBA overexpression inhibited HIPPO signaling by upregulating YAP protein expression and promotes proliferation in gastric cancer cells. This is consistent with the results of this experiment.

\section{Materials and Methods}

\subsection{Plant Materials and Oil Extraction}

The fresh pinecones of Pinus koraiensis were obtained from Yichun Hongxing District Forestry Bureau (Yichun, China), in October 2018. The air-dried pinecones were grinded into powder (particle size $<840 \mu \mathrm{m}$ ) and treated with hydrodistillation in a Clevenger-type apparatus for $4 \mathrm{~h}$. The PEO was stored at $-20^{\circ} \mathrm{C}$ until experimental studies. 


\subsection{GC/MS Analysis}

GC/MS analysis was performed by a gas chromatography $(6890 \mathrm{~N}$, Agilent Technologies, Santa Clara, CA, USA) coupled with a mass spectrometer (5975N, Agilent Technologies, Santa Clara, CA, USA) operating at $70 \mathrm{eV}$ ionization energy equipped with a DB-5-MS capillary column $(30 \mathrm{~m} \times 0.25 \mathrm{~mm} \times 0.25 \mu \mathrm{m})$. The injector and detector temperatures were maintained at $280{ }^{\circ} \mathrm{C}$. The temperature timeline of the oven was programmed as follows: The initial temperature was set to be $40{ }^{\circ} \mathrm{C}$ and was then allowed to increase to $150{ }^{\circ} \mathrm{C}$. Finally, the temperature increased to $310^{\circ} \mathrm{C}$ kept for $5 \mathrm{~min}$. $1 \mathrm{~mL}$ of PEO was dissolved in $\mathrm{n}$-hexane and injected; and the split mode was 1:50. Helium was used as the carrier gas with a flow rate of $1.0 \mathrm{~mL} / \mathrm{min}$. Then, the MSD Chem Station Software (AMDIS-32, Agilent Technologies, Santa Clara, CA, USA) was used to handle mass spectra and chromatograms. Most constituents were tentatively identified by comparison of their retention indices (RIs), established in accordance with reference to a homologous series of C8-C40 n-alkanes that had been injected following the injection of the PEO under the same chromatographic conditions. The component identification of $\mathrm{PEO}$ was performed by comparing retention indices and matching the recorded mass spectra of each compound with NIST 17 Mass Spectral libraries.

\subsection{In Vitro Anti-Tumors Assay}

\subsubsection{Cytotoxicity Assay}

The MGC-803 cell line was obtained from Cancer Hospital Affiliated to Harbin Medical University (Harbin, China). Cytotoxicity assay was determined by MTT assay, the experimental steps referred to the previous reports $[6,57]$. The concentration of DMSO in the medium was kept in $0.1 \%(w / v)$. The MGC-803 cells $\left(1 \sim 5 \times 10^{4}\right)$ were cultured in 96-well plates and treated with a various of PEO concentrations $(0.1 \sim 0.9 \mathrm{mg} / \mathrm{mL})$ for 24,48 , and $72 \mathrm{~h}$. $10 \mu \mathrm{L}$ MTT solution $(5 \mathrm{mg} / \mathrm{mL})$ was added to cells and incubated for $4 \mathrm{~h}$ at $37^{\circ} \mathrm{C}$. Then, the medium was removed and $150 \mu \mathrm{L}$ DMSO was added to cells. The absorbance was determined at $490 \mathrm{~nm}$. Paclitaxel (Aladdin, Shanghai, China) was used as a positive control drug. All experiments were undertaken in sextuplicate. The cell proliferation activity was calculated as follows: Inhibition rate $(\%)=\left(A_{0}-A_{1}\right) / A_{0} \times 100, A_{1}$ represented the absorbance of the experimental groups, while $\mathrm{A}_{0}$ represented the absorbance of the control group.

\subsubsection{Scratch Wound-Healing Assay}

Cell scratch assay was performed as previously reported [58]. The logarithmic phase MGC-803 cells were grown in a 6-well plate with appropriate density until cells covering the whole dish and starved overnight in DMEM media with $1 \%$ fetal bovine serum (Sigma-Aldrich, St. Louis, MO, USA). After making the linear scratch, the medium was removed and plates were washed three times with PBS. The cells were treated with various concentrations of PEO $(0,25,50$, and $100 \mu \mathrm{g} / \mathrm{mL})$ for $24 \mathrm{~h}$. The medium was discarded and photos were taken immediately under an inverted phase contrast microscope selecting 10 fields. The width of the scratched area was measured by Image J software.

\subsubsection{Cell Cycle Analysis}

The MGC 803 cells $\left(1 \sim 5 \times 10^{5}\right)$ in the logarithmic phase were cultured in a 6-well plate at $37^{\circ} \mathrm{C}$, $5 \% \mathrm{CO}_{2}(v / v)$ for $10 \sim 12 \mathrm{~h}$. After treating MGC-803 cells with PEO at different concentrations $(0,25,50$, and $100 \mu \mathrm{g} / \mathrm{mL}$ ) for $24 \mathrm{~h}$, cells were centrifuged and stained with $50 \mu \mathrm{g} / \mathrm{mL}$ PI and $100 \mu \mathrm{g} / \mathrm{mL}$ RNase A for $30 \mathrm{~min}$ in the dark at room temperature. All operations were carried out in accordance with the requirements of the cell cycle detection kit (Beyotime Biotechnology, Shanghai, China). The samples were analyzed by flow cytometer, and the data were analyzed by using the ModFit LT software (Verity Software House, Topsham, ME, USA) [59]. 


\subsubsection{Apoptosis Analysis}

All operations were carried out in accordance with the requirements of the Annexin V-FITC/PI Kit (4A Biotech Co., Ltd., Beijing, China). The logarithmic phase MGC-803 cells $\left(1 \sim 5 \times 10^{5}\right)$ were grown in a 6-well plate culturing for $12 \mathrm{~h}$, then the cells were treated with various concentrations of $\operatorname{PEO}(0,25$, 50 , and $100 \mu \mathrm{g} / \mathrm{mL}$ ) for $24 \mathrm{~h}$. After cells were centrifuged and the medium was discarded, cells were washed with the pre-cooled PBS. A total of $1 \sim 5 \times 10^{6}$ cells were resuspended in the Binding Buffer, then added in $5 \mu \mathrm{L}$ Annexin V/FITC and incubated for $3 \mathrm{~min}$ at room temperature in the dark. Finally, $10 \mu \mathrm{L}$ and $20 \mu \mathrm{g} / \mathrm{mL}$ PI were added and the samples were analyzed by flow cytometer immediately.

\subsubsection{Measurement of the Mitochondrial Membrane Potential $(\Delta \Psi \mathrm{m})$ with JC-1}

The Mitochondrial membrane potential of MGC-803 cells treated with PEO was measured by JC-1 dye (Solarbio, Beijing, China). The MGC-803 cells in the logarithmic phase were cultured in a 6-well plate at $37{ }^{\circ} \mathrm{C}, 5 \% \mathrm{CO}_{2}(v / v)$ at a density of $3 \sim 5 \times 10^{5}$ cells per well. After $24 \mathrm{~h}$ of treatment with different concentrations PEO $(0,25,50$, and $100 \mu \mathrm{g} / \mathrm{mL})$, cells were centrifuged and collected. $1 \mathrm{~mL}$ Jc-1 reagent (the concentration of Jc- 1 was $10 \mu \mathrm{g} / \mathrm{mL}$ ) was added to each centrifuge tube and incubated for $20 \mathrm{~min}$ at $37^{\circ} \mathrm{C}$. Then, the samples were rinsed twice with PBS and analyzed by flow cytometer.

\subsection{The Mechanism of PEO on MGC-803 Cells}

\subsubsection{RNA Extraction and Sequencing}

After the treatment with PEO for $24 \mathrm{~h}$, total RNA was extracted using TRIzol reagent (Thermo Fisher Scientific, Waltham, MA, USA) and the RNeasy kit (Qiagen, Hilden, Germany) according to the manufacturer's instructions. The integrity of the total RNA was checked by agarose gel electrophoresis, and NanoDrop ND-1000 was used for quantitative and further quality control. A total of six samples were available, including three samples of test groups (T-1, T-2, and T-3) and three samples of control groups (C-1, C-2, and C-3). 1 2 $\mu \mathrm{g}$ total RNA was selected from each sample for sequencing library construction. The mRNA of total RNA was enriched using the NEB Next ${ }^{\circledR} \operatorname{Poly}(A)$ mRNA Magnetic Isolation Module (New England Biolabs, USA) (or the rRNA was removed using RiboZero Magnetic Gold Kit, Epicentre, Charlotte, NC, USA). After treatment, the product RNA was constructed by the Library using KAPA Stranded RNA-Seq Library Prep Kit (Illumina, San Diego, CA, USA). The constructed library was checked by Agilent 2100 Bioanalyzer (library concentration, fragment size 400-600 bp, whether there were junctions, etc.) and the final quantification of the library was carried out by qPCR. The clustering of the index-coded samples was performed on a cBot Cluster Generation System by using TruSeq SR Cluster Kit v3-cBot-HS (\#GD-401-3001, Illumina, San Diego, CA, USA) according to the manufacturer's instructions. After cluster generation, the libraries were sequenced on an Illumina Hiseq 4000 (Illumina, San Diego, CA, USA) and 150 bp paired-end reads were generated. Accession numbers: GSE137480 [NCBI tracking system \#20316023].

\subsubsection{Differential Gene Expression Analysis}

Ballgown was used to quantify the expression level of samples and to analyze the differential expression of genes between the control and the experimental groups. The criteria for this analysis were FPKM (Fragments per kilobase of transcript per million mapped reads) $\geq 0.5$ and $p$ value $\leq 0.05$.

\subsubsection{Gene Ontology (GO) and Pathway Analysis}

GO is a gene functional classification entry that includes three sub-items of molecular function, cellular composition, and involved biological processes. We used GO analysis to determine which specific functional items are most directly associated with the DEGs. Pathway analysis was used to determine the significant pathways in which DEGs participate. 


\subsubsection{Real-Time PCR Analysis}

DNA amplification and detection were performed with a ViiA 7 Real-time PCR System (Applied Biosystems) to confirm the RNA-seq result. The full primer list is shown in Supplementary and Table 3. The real-time polymerase chain reaction (real-time PCR) amplifications were carried out in a total reaction volume of $10 \mu \mathrm{L}$, containing $2 \mu \mathrm{L}$ of DNA extract. The reaction mixture contained $2.0 \mu \mathrm{L}$ water (Roche, Mannheim, Germany), $5 \mu \mathrm{L}$ of master mix $2 \times$ (Arraystar, Rockville, MD, USA), and $0.5 \mu \mathrm{L}$ of each primer $(10 \mu \mathrm{M})$. Real-time PCR was performed with the following conditions: $95^{\circ} \mathrm{C} / 10 \mathrm{~min}$ followed by 40 cycles of $95^{\circ} \mathrm{C} / 10 \mathrm{~s}, 60^{\circ} \mathrm{C} / 60 \mathrm{~s}$. Finally, a melting curve was performed by heating $95^{\circ} \mathrm{C} / 10 \mathrm{~s}, 60^{\circ} \mathrm{C} / 60 \mathrm{~s}, 95^{\circ} \mathrm{C} / 15 \mathrm{~s}$, and heating again from 60 to $99^{\circ} \mathrm{C}$.

Table 3. The primers used for real-time PCR analysis.

\begin{tabular}{cc}
\hline Gene & Bidirectional Primer Sequence \\
\hline \multirow{2}{*}{ GAPDH (HUMAN) } & F:5' GGGAAACTGTGGCGTGAT 3' \\
& F:5' GAGTGGGTGTCGCTGTTGA 3' \\
LATS2 & R:5' TGGTGGAGTGTTGGAGTGAT 3' \\
& F:5' GCCAGCAGGTTGGGAGAT 3' \\
YAP1 & R:5'TGTGATTTAAGAAGTATCTCTGACC 3' \\
& F:5' TGTCACCGACTACCACAAA 3' \\
AJUBA & R:5' ATCACCCTCACGATGTCC 3' \\
& F:5' ATTTAGGACCAGAAGCGAGAA 3' \\
FAT4 & R:5' CTCTCCACTTTCCCAGCAA 3' \\
& F:5' TCAAGAATGCCAAACCTGTA 3' \\
STK3 & R:5' GGATTCCAACATCGTGCTA 3' \\
\end{tabular}

\subsubsection{Western Blot Analysis}

The experimental steps referred to the previous reports [57]. MGC-803 cells were collected after treatment with PEO $(0,25,50$, and $100 \mu \mathrm{g} / \mathrm{mL})$ for $24 \mathrm{~h}$ and then lysed in an ice-cold RIPA buffer (Aladdin Industrial Corporation, Shanghai, China). After centrifugation at 12,000 rpm for $10 \mathrm{~min}$, the protein in the supernatant was quantified by bicinchoninic acid (BCA) protein assay kit (Beyotime Co, Shanghai, China). The proteins in each sample were separated via SDS polyacrylamide on a $10 \%$ gel and transferred to PVDF membrane. Blocked with 5\% non-fat milk for $1 \mathrm{~h}$ at room temperature, then the membranes were incubated with $\beta$-actin, FAT4 (ABGENT, San Diego, CA, USA), STK3, LATS2, YAP1, and AJUBA antibodies (WUHAN SANYING, Wuhan, China) overnight at $4{ }^{\circ} \mathrm{C}$, washing with TBST, and then incubated with HRP-conjugated secondary antibodies for $1 \mathrm{~h}$ at room temperature. Proteins were detected by ECL procedures (Thermo Fisher Scientific, Waltham, MA, USA) and analyzed by Image J software. The experiments were repeated three times.

\subsection{Statistical Analysis}

All experiments were repeated three times, and the experimental data were presented in the form of mean \pm SD. One-way analysis of variance (ANOVA) were used to analyze significant differences. $p<0.05$ was considered to indicate a statistically significant result. The criterion for statistically significant results was $p<0.05$.

\section{Conclusions}

The experimental results show that PEO had good anti-tumor activity on MGC-803 cells. The results of RNA sequencing showed that the related genes FAT4, STK3, LATS2, YAP1, and AJUBA of HIPPO signaling pathway had significant changes, which were verified by real-time PCR and Western blot experiments. These results suggested that HIPPO signaling pathway was indeed involved in the anti-tumor activity of PEO on MGC-803 cells, but these did not prove that HIPPO signaling pathway was the only pathway in the anti-tumor mechanism. This study provided a theoretical basis and research 
direction for the next study on the anti-tumor mechanism of PEO. It is useful for the development of natural anti-tumor drugs and the comprehensive utilization of Pinus koraiensis resources.

Supplementary Materials: The full primer list is available as online at http://www.mdpi.com/1420-3049/24/21/ $3851 / s 1$.

Author Contributions: Conceptualization, Z.W. and Y.Z.; Methodology, Y.Z., C.X. and J.Q.; Software, Y.Z., C.X., and J.Q.; Validation, Y.Z., Z.W., C.X. and J.Q.; Formal analysis, Y.Z.; Investigation, Y.Z.; Resources, Z.W.; Data curation, Y.Z.; Writing—original draft preparation, Y.Z.; Writing—review and editing, Y.Z. and C.X.; Supervision, Z.W.

Funding: This research was funded by the National Key Research and Development Program of China, grant number 2016YFC0500305-02.

Acknowledgments: The authors thank Shen Ji-min from the Environmental Engineering, Harbin Institute of Technology, for his helpful suggestions and assistance.

Conflicts of Interest: The authors declare no conflict of interest.

\section{References}

1. Tan, P.; Yeoh, K.-G. Genetics and molecular pathogenesis of gastric adenocarcinoma. Gastroenterology 2015, 149, 1153-1162. [CrossRef] [PubMed]

2. Qiao, Y.; Li, T.; Zheng, S.; Wang, H. The hippo pathway as a drug target in gastric cancer. Cancer Lett. 2018, 420, 14-25. [CrossRef] [PubMed]

3. Kuo, C.-Y.; Chao, Y.; Li, C.-P. Update on treatment of gastric cancer. J. Chin. Med. Assoc. 2014, 77, 345-353. [CrossRef] [PubMed]

4. Jakubek, M.; Kejík, Z.; Kaplánek, R.; Hromádka, R.; Šandriková, V.; Sýkora, D.; Antonyová, V.; Urban, M.; Dytrych, P.; Mikula, I.; et al. Strategy for improved therapeutic efficiency of curcumin in the treatment of gastric cancer. Biomed. Pharmacother. 2019, 118, 109278. [CrossRef] [PubMed]

5. Zhao, Y.; Tang, H.; Zeng, X.; Ye, D.; Liu, J. Resveratrol inhibits proliferation, migration and invasion via Akt and ERK1/2 signaling pathways in renal cell carcinoma cells. Biomed. Pharmacother. 2018, 98, 36-44. [CrossRef] [PubMed]

6. Qiu, J.; Zhang, H.; Wang, Z.; Liu, S.; Regenstein, J.M. Response surface methodology for the synthesis of an Auricularia auriculajudae polysaccharides-CDDP complex. Int. J. Biol. Macromol. 2016, 93, 333-343. [CrossRef]

7. Nascimento, K.F.D.; Moreira, F.M.F.; Santos, J.A.; Kassuya, C.A.L.; Croda, J.H.R.; Cardoso, C.A.L.; Vieira, M.D.C.; Ruiz, A.L.T.G.; Foglio, M.A.; De Carvalho, J.E.; et al. Antioxidant, anti-inflammatory, antiproliferative and antimycobacterial activities of the essential oil of Psidium guineense Sw. and spathulenol. J. Ethnopharmacol. 2018, 210, 351-358. [CrossRef]

8. Lang, M.; Ferron, P.-J.; Bursztyka, J.; Montjarret, A.; Duteil, E.; Bazire, A.; Bedoux, G. Evaluation of immunomodulatory activities of essential oils by high content analysis. J. Biotechnol. 2019, 303, 65-71. [CrossRef]

9. Luo, W.; Du, Z.; Zheng, Y.; Liang, X.; Huang, G.; Zhang, Q.; Liu, Z.; Zhang, K.; Zheng, X.; Lin, L.; et al. Phytochemical composition and bioactivities of essential oils from six Lamiaceae species. Ind. Crop. Prod. 2019, 133, 357-364. [CrossRef]

10. Ait Babahmad, R.; Aghraz, A.; Boutafda, A.; Papazoglou, E.G.; Tarantilis, P.A.; Kanakis, C.; Hafidi, M.; Ouhdouch, Y.; Outzourhit, A.; Ouhammou, A. Chemical composition of essential oil of Jatropha curcas, L. Leaves and its antioxidant and antimicrobial activities. Ind. Crop. Prod. 2018, 121, 405-410. [CrossRef]

11. Sadekuzzaman, M.; Mizan, M.F.R.; Kim, H.-S.; Yang, S.; Ha, S.-D. Activity of thyme and tea tree essential oils against selected foodborne pathogens in biofilms on abiotic surfaces. LWT 2018, 89, 134-139. [CrossRef]

12. Maurya, A.K.; Mohanty, S.; Pal, A.; Chanotiya, C.S.; Bawankule, D.U. The essential oil from Citrus limetta Risso peels alleviates skin inflammation: In-vitro and in-vivo study. J. Ethnopharmacol. 2018, 212, 86-94. [CrossRef] [PubMed]

13. Elkady, W.M.; Ayoub, I.M. Chemical profiling and antiproliferative effect of essential oils of two Araucaria species cultivated in Egypt. Ind. Crop. Prod. 2018, 118, 188-195. [CrossRef]

14. Pascual-Villalobos, M.; Cantó-Tejero, M.; Vallejo, R.; Guirao, P.; Rodríguez-Rojo, S.; Cocero, M. Use of nanoemulsions of plant essential oils as aphid repellents. Ind. Crop. Prod. 2017, 110, 45-57. [CrossRef] 
15. Yi, J.; Wang, Z.; Bai, H.; Yu, X.; Jing, J.; Zuo, L. Optimization of purification, identification and evaluation of the in vitro antitumor activity of polyphenols from Pinus koraiensis pinecones. Molecules 2015, 20, 10450-10467. [CrossRef]

16. Yi, J.; Li, S.; Wang, C.; Cao, N.; Qu, H.; Cheng, C.; Wang, Z.; Wang, L.; Zhou, L. Potential applications of polyphenols on main ncRNAs regulations as novel therapeutic strategy for cancer. Biomed. Pharmacother. 2019, 113, 108703. [CrossRef]

17. Yi, J.; Cheng, C.; Li, S.; Wang, D.; Wang, L.; Wang, Z. Preparation optimization and protective effect on $60 \mathrm{Co}-\gamma$ radiation damage of Pinus koraiensis pinecone polyphenols microspheres. Int. J. Biol. Macromol. 2018, 113, 583-591. [CrossRef]

18. Lee, T.K.; Park, J.Y.; Yu, J.S.; Jang, T.S.; Oh, S.T.; Pang, C.; Ko, Y.-J.; Kang, K.S.; Kim, K.H. $7 \alpha, 15$-Dihydroxydehydroabietic acid from Pinus koraiensis inhibits the promotion of angiogenesis through downregulation of VEGF, p-Akt and p-ERK in HUVECs. Bioorg. Med. Chem. Lett. 2018, 28, 1084-1089. [CrossRef]

19. Mitić, Z.S.; Jovanović, B.; Jovanović, S.; Mihajilov-Krstev, T.; Stojanović-Radić, Z.Z.; Cvetković, V.J.; Mitrović, T.L.; Marin, P.D.; Zlatković, B.K.; Stojanović, G.S. Comparative study of the essential oils of four Pinus species: Chemical composition, antimicrobial and insect larvicidal activity. Ind. Crop. Prod. 2018, 111, 55-62.

20. Wu, Y.-P.; Liang, X.; Liu, X.-Y.; Zhong, K.; Gao, B.; Huang, Y.-N.; Gao, H. Cedrus deodara pine needle as a potential source of natural antioxidants: Bioactive constituents and antioxidant activities. J. Funct. Foods 2015, 14, 605-612. [CrossRef]

21. Maugeri-Saccà, M.; De Maria, R. The Hippo pathway in normal development and cancer. Pharmacol. Therapeut. 2018, 186, 60-72. [CrossRef] [PubMed]

22. Wang, Y.; Xu, X.; Maglic, D.; Dill, M.T.; Mojumdar, K.; Ng, P.K.-S.; Jeong, K.J.; Tsang, Y.H.; Moreno, D.; Bhavana, V.H.; et al. Comprehensive molecular characterization of the hippo signaling pathway in cancer. Cell Rep. 2018, 25, 1304-1317. [CrossRef] [PubMed]

23. Zhou, Y.; Huang, T.; Zhang, J.; Cheng, A.S.; Yu, J.; Kang, W.; To, K.F. Emerging roles of Hippo signaling in inflammation and YAP-driven tumor immunity. Cancer Lett. 2018, 426, 73-79. [CrossRef] [PubMed]

24. Zhao, Q.; Jia, X.; Zhang, Y.; Dong, Y.; Lei, Y.; Tan, X.; Williamson, R.A.; Wang, A.; Zhang, D.; Ma, J. Tetrandrine induces apoptosis in human neuroblastoma through regulating the Hippo/YAP signaling pathway. Biochem. Bioph. Res. Commun. 2019, 513, 846-851. [CrossRef] [PubMed]

25. Wang, T.; Mao, B.; Cheng, C.; Zou, Z.; Gao, J.; Yang, Y.; Lei, T.; Qi, X.; Yuan, Z.; Xu, W.; et al. YAP promotes breast cancer metastasis by repressing growth differentiation factor-15. Biochim. Biophys. Acta Mol. Basis Dis. 2018, 1864, 1744-1753. [CrossRef] [PubMed]

26. Yin, K.; Dang, S.; Cui, L.; Fan, X.; Wang, L.; Xie, R.; Qu, J.; Shang, M.; Chen, J.; Xu, Z. Netrin-1 promotes metastasis of gastric cancer by regulating YAP activity. Biochem. Bioph. Res. Commun. 2018, 496, 76-82. [CrossRef]

27. Bhandari, K.B.; West, C.; Klein, D.; Subbiah, S.; Surowiec, K. Essential oil composition of 'WW-B.Dahl' old world bluestem (Bothriochloa bladhii) grown in the Texas High Plains. Ind. Crop. Prod. 2019, 133, 1-9. [CrossRef]

28. Nirmal, N.P.; Mereddy, R.; Li, L.; Sultanbawa, Y. Formulation, characterisation and antibacterial activity of lemon myrtle and anise myrtle essential oil in water nanoemulsion. Food Chem. 2018, 254, 1-7. [CrossRef]

29. Mitić, Z.S.; Jovanović, B.; Jovanović, S.Č.; Stojanović-Radić, Z.Z.; Mihajilov-Krstev, T.; Jovanović, N.M.; Nikolić, B.M.; Marin, P.D.; Zlatković, B.K.; Stojanović, G.S. Essential oils of Pinus halepensis and P. heldreichii: Chemical composition, antimicrobial and insect larvicidal activity. Ind. Crop. Prod. 2019, 140, 111702. [CrossRef]

30. Ray, A.; Jena, S.; Dash, B.; Kar, B.; Halder, T.; Chatterjee, T.; Ghosh, B.; Panda, P.C.; Nayak, S.; Mahapatra, N. Chemical diversity, antioxidant and antimicrobial activities of the essential oils from Indian populations of Hedychium coronarium Koen. Ind. Crop. Prod. 2018, 112, 353-362. [CrossRef]

31. Tao, Y.; Song, Y.; Han, T.; Wang, C.; Zhao, T.; Gu, Y. miR-205 Regulation of ICT1 has an oncogenic potential via promoting the migration and invasion of gastric cancer cells. Biomed. Pharmacother. 2017, 96, 191-197. [CrossRef] [PubMed] 
32. Zhang, Y.; Chen, S.; Wei, C.; Rankin, G.O.; Ye, X.; Chen, Y.C. Flavonoids from Chinese bayberry leaves induced apoptosis and G1 cell cycle arrest via Erk pathway in ovarian cancer cells. Eur. J. Med. Chem. 2018, 147, 218-226. [CrossRef] [PubMed]

33. Azevedo-Barbosa, H.; Ferreira-Silva, G.Á.; Silva, C.F.; De Souza, T.B.; Dias, D.F.; De Paula, A.C.C.; Ionta, M.; Carvalho, D.T. Phenylpropanoid-based sulfonamide promotes cyclin D1 and cyclin E down-regulation and induces cell cycle arrest at G1/S transition in estrogen positive MCF-7 cell line. Toxicol. In Vitro 2019, 59, 150-160. [CrossRef] [PubMed]

34. Sadeghi, S.; Davoodvandi, A.; Pourhanifeh, M.H.; Sharifi, N.; Arefnezhad, R.; Sahebnasagh, R.; Moghadam, S.A.; Sahebkar, A.; Mirzaei, H. Anti-cancer effects of cinnamon: Insights into its apoptosis effects. Eur. J. Med. Chem. 2019, 178, 131-140. [CrossRef] [PubMed]

35. Quassinti, L.; Maggi, F.; Ortolani, F.; Lupidi, G.; Petrelli, D.; Vitali, L.A.; Miano, A.; Bramucci, M. Exploring new applications of tulip tree (Liriodendron tulipifera L.): Leaf essential oil as apoptotic agent for human glioblastoma. Environ. Sci. Pollut. Res. 2019, 1-13. [CrossRef]

36. Chen, W.; Wang, H.; Liu, Y.; Xu, W.; Ling, C.; Li, Y.; Liu, J.; Chen, M.; Zhang, Y.; Chen, B.; et al. Linc-RoR promotes proliferation, migration, and invasion via the Hippo/YAP pathway in pancreatic cancer cells. J. Cell. Biochem. 2019. [CrossRef]

37. Raut, J.S.; Karuppayil, S.M. A status review on the medicinal properties of essential oils. Ind. Crop. Prod. 2014, 62, 250-264. [CrossRef]

38. Ribeiro-Santos, R.; Andrade, M.; De Melo, N.R.; Sanches-Silva, A. Use of essential oils in active food packaging: Recent advances and future trends. Trends Food Sci. Technol. 2017, 61, 132-140. [CrossRef]

39. Pavela, R.; Benelli, G. Essential oils as ecofriendly biopesticides? Challenges and constraints. Trends Plant. Sci. 2016, 21, 1000-1007. [CrossRef]

40. Mohagheghniapour, A.; Saharkhiz, M.J.; Golmakani, M.T.; Niakousari, M. Variations in chemical compositions of essential oil from sour orange (Citrus aurantium L.) blossoms by different isolation methods. Sustain. Chem. Pharm. 2018, 10, 118-124. [CrossRef]

41. Galdino, P.M.; Nascimento, M.V.M.; Florentino, I.F.; Lino, R.C.; Fajemiroye, J.O.; Chaibub, B.A.; De Paula, J.R.; De Lima, T.C.M.; Costa, E.A. The anxiolytic-like effect of an essential oil derived from Spiranthera odoratissima A. St. Hil. leaves and its major component, $\beta$-caryophyllene, in male mice. Prog. Neuropsychopharmacol. Biol. Psychiatry 2012, 38, 276-284. [CrossRef] [PubMed]

42. Yi, F.; Sun, J.; Bao, X.; Ma, B.; Sun, M. Influence of molecular distillation on antioxidant and antimicrobial activities of rose essential oils. LWT 2019, 102, 310-316. [CrossRef]

43. Chen, J.; Lu, M.; Jing, Y.; Dong, J. The synthesis of 1-carvone and limonene derivatives with increased antiproliferative effect and activation of ERK pathway in prostate cancer cells. Bioorg. Med. Chem. 2006, 14, 6539-6547. [CrossRef] [PubMed]

44. El-Abid, H.; Amaral, C.; Cunha, S.C.; Augusto, T.V.; Fernandes, J.O.; Correia-Da-Silva, G.; Teixeira, N.; Moumni, M. Chemical composition and anti-cancer properties of Juniperus oxycedrus L. essential oils on estrogen receptor-positive breast cancer cells. J. Funct. Foods 2019, 59, 261-271. [CrossRef]

45. Chen, W.; Liu, Y.; Li, M.; Mao, J.; Zhang, L.; Huang, R.; Jin, X.; Ye, L. Anti-tumor effect of $\alpha$-pinene on human hepatoma cell lines through inducing G2/M cell cycle arrest. J. Pharmacol. Sci. 2015, 127, 332-338. [CrossRef]

46. Vandresen, F.; Falzirolli, H.; Almeida Batista, S.A.; Da Silva-Giardini, A.P.B.; de Oliveira, D.N.; Catharino, R.R.; Ruiz, A.L.T.G.; de Carvalho, J.E.; Foglio, M.A.; Da Silva, C.C. Novel R-(+)-limonene-based thiosemicarbazones and their antitumor activity against human tumor cell lines. Eur. J. Med. Chem. 2014, 79, 110-116. [CrossRef]

47. Bouyahya, A.; Belmehdi, O.; El Jemli, M.; Marmouzi, I.; Bourais, I.; Abrini, J.; Faouzi, M.E.A.; Dakka, N.; Bakri, Y. Chemical variability of Centaurium erythraea essential oils at three developmental stages and investigation of their in vitro antioxidant, antidiabetic, dermatoprotective and antibacterial activities. Ind. Crop. Prod. 2019, 132, 111-117. [CrossRef]

48. Zhang, J.; Huang, R.-Z.; Cao, H.-J.; Cheng, A.-W.; Jiang, C.-S.; Liao, Z.-X.; Liu, C.; Sun, J.-Y. Chemical composition, in vitro anti-tumor activities and related mechanisms of the essential oil from the roots of Potentilla discolor. Ind. Crop. Prod. 2018, 113, 19-27. [CrossRef]

49. Poma, P.; Labbozzetta, M.; McCubrey, J.A.; Ramarosandratana, A.V.; Sajeva, M.; Zito, P.; Notarbartolo, M. Antitumor Mechanism of the Essential Oils from Two Succulent Plants in Multidrug Resistance Leukemia Cell. Pharmaceuticals 2019, 12, 124. [CrossRef] 
50. Wang, R.; Li, J.; Zhao, Y.; Li, Y.; Yin, L. Investigating the therapeutic potential and mechanism of curcumin in breast cancer based on RNA sequencing and bioinformatics analysis. Breast Cancer-Tokyo 2018, 25, 206-212. [CrossRef]

51. Zhao, X.; Liu, Z.; Liu, Z.; Meng, R.; Shi, C.; Chen, X.; Bu, X.; Guo, N. Phenotype and RNA-seq-Based transcriptome profiling of Staphylococcus aureus biofilms in response to tea tree oil. Microb. Pathog. 2018, 123, 304-313. [CrossRef] [PubMed]

52. Yu, H.-X.; Yao, Y.; Bu, F.-T.; Chen, Y.; Wu, Y.-T.; Yang, Y.; Chen, X.; Zhu, Y.; Wang, Q.; Pan, X.-Y.; et al. Blockade of YAP alleviates hepatic fibrosis through accelerating apoptosis and reversion of activated hepatic stellate cells. Mol. Immunol. 2019, 107, 29-40. [CrossRef] [PubMed]

53. Bi, L.; Ma, F.; Tian, R.; Zhou, Y.; Lan, W.; Song, Q.; Cheng, X. AJUBA increases the cisplatin resistance through hippo pathway in cervical cancer. Gene 2018, 644, 148-154. [CrossRef]

54. Plouffe, S.W.; Hong, A.W.; Guan, K.-L. Disease implications of the Hippo/YAP pathway. Trends Mol. Med. 2015, 21, 212-222. [CrossRef] [PubMed]

55. Das Thakur, M.; Feng, Y.; Jagannathan, R.; Seppa, M.J.; Skeath, J.B.; Longmore, G.D. Ajuba LIM proteins are negative regulators of the Hippo signaling pathway. Curr. Biol. 2010, 20, 657-662. [CrossRef] [PubMed]

56. Li, H.; Fu, L.; Liu, B.; Lin, X.; Dong, Q.; Wang, E. Ajuba overexpression regulates mitochondrial potential and glucose uptake through YAP/Bcl-xL/GLUT1 in human gastric cancer. Gene 2019, 693, 16-24. [CrossRef] [PubMed]

57. Li, Z.; Chen, Y.; An, T.; Liu, P.; Zhu, J.; Yang, H.; Zhang, W.; Dong, T.; Jiang, J.; Zhang, Y.; et al. Nuciferine inhibits the progression of glioblastoma by suppressing the SOX2-AKT/STAT3-Slug signaling pathway. J. Exp. Clin. Canc. Res. 2019, 38, 139. [CrossRef] [PubMed]

58. Geng, P.-F.; Wang, C.-C.; Li, Z.-H.; Hu, X.-N.; Zhao, T.-Q.; Fu, D.-J.; Zhao, B.; Yu, B.; Liu, H.-M. Design, synthesis and preliminary biological evaluation of 5,8-dihydropteridine-6,7-diones that induce apoptosis and suppress cell migration. Eur. J. Med. Chem. 2018, 143, 1959-1967. [CrossRef]

59. Fu, D.-J.; Song, J.; Hou, Y.-H.; Zhao, R.-H.; Li, J.-H.; Mao, R.-W.; Yang, J.-J.; Li, P.; Zi, X.-L.; Li, Z.-H.; et al. Discovery of 5,6-diaryl-1,2,4-triazines hybrids as potential apoptosis inducers. Eur. J. Med. Chem. 2017, 138, 1076-1088. [CrossRef]

Sample Availability: Samples of the compounds are not available from the authors.

(C) 2019 by the authors. Licensee MDPI, Basel, Switzerland. This article is an open access article distributed under the terms and conditions of the Creative Commons Attribution (CC BY) license (http://creativecommons.org/licenses/by/4.0/). 